\title{
Tingkat Pencemaran Air sungai Tondano di Kelurahan Ternate Baru Kota Manado
}

\author{
(Water pollution level of Tondano River at Ternate Baru Village, Manado)
}

\author{
Melky Lensun, Sipriana Tumembouw
}

\begin{abstract}
The objective of this research was to detect the pollution level of Tondano River based on temperature, BOD, turbidity and dissolved oxygen parameters. Research was conducted at Ternate Baru Village, Manado City, from January to March 2013. Water sample was taken by purposive sampling at three stations at 08.00 AM, 11.00 AM, and 15.00 PM, each with two sampling points. Water quality was measured in situ for temperature and turbidity while dissolved oxygen and BOD were analysed in laboratory. Research results found temperature ranged from $27^{0} \mathrm{C}-27,8{ }^{0} \mathrm{C}$, turbiduty 37,9 - $150 \mathrm{NTU}$, dissolved oxygen 6,3 - 7,5 mg/L and BOD 15,5-44,5 mg/L. Based on Water Quality Standard Grade II PP No. 82, 2001, BOD and turbidity at Ternate Baru were high. It was concluded that water quality of Tondano River at Ternate Baru Village was categorized polluted.
\end{abstract}

Keywords: water quality, pollution, Tondano River, Ternate Baru Village

\section{PENDAHULUAN}

Sungai adalah salah satu sumber daya alam yang bersifat mengalir (flowing resource), sehingga pemanfaatan di hulu dapat menurunkan kualitas air, pencemaran dan biaya sosial bagi pelestariannya (Azwir, 2006). Daerah Aliran Sungai Tondano terdiri atas sub Daerah Aliran Sungai (DAS) Noongan, Tikala, Klabat, dan Tondano, berada di kawasan strategis karena melintasi zona pertumbuhan ekonomi terpadu antara dua Kabupaten dan dua Kota di Propinsi Sulawesi Utara. Sungai Tondano adalah satu-satunya outlet dari Danau Tondano, mengalir sepanjang 44,6 Km yang bermuara di Teluk Manado. Hal itu dapat dilihat dari manfaat ganda di samping sebagai sumber air untuk irigasi pertanian, sumber energi Pembangkit Listrik Tenaga Air (PLTA), juga dimanfaatkan untuk air minum (PT. AIR Manado), media transportasi, dan pariwisata (Hunta, 2011). Kontradiksi pemanfaatan DAS Tondano adalah tekanan-tekanan yang mengakibatkan turunnya daya dukung dan kualitas air, dimana kegiatan masyarakat dan industri dalam hal limbah buangan adalah kontributor utama. Tekanan-tekanan pada wilayah sungai ini telah mengakibatkan begitu banyak dampak yang langsung dirasakan oleh penduduk, diantaranya kematian ikan dalam karamba, penyakit kulit pada masyarakat dan nilai estetika sungai yang rusak akibat peletakan karamba ikan.

Menurut PP. No. 38 Tahun 2011 tentang Sungai didefinisikan bahwa, sungai adalah alur atau wadah alami dan /atau buatan berupa jaringan pengaliran air beserta air di dalamnya, mulai dari hulu sampai muara dengan dibatasi kanan dan kiri oleh garis sempadan. Sungai merupakan perairan 
umum dengan pergerakan air satu arah yang terus menerus. Ekosistem sungai merupakan habitat bagi biota air yang keberadaannya sangat dipengaruhi oleh lingkungan sekitarnya. Sungai juga merupakan sumber air bagi masyarakat yang dimanfaatkan untuk berbagai keperluan dan kegiatan, seperti kebutuhan rumah tangga, pertanian, industri, sumber mineral, dan pemanfaatan lainnya. Kegiatan-kegiatan tersebut bila tidak dikelola dengan baik akan berdampak negatif terhadap sumberdaya air, diantaranya adalah menurunnya kualitas air. Kondisi ini dapat menimbulkan gangguan, kerusakan, dan bahaya bagi mahkluk hidup yang bergantung pada sumberdaya air (Wijaya, 2009)

Pencemaran air sungai sangat ditentukan oleh kegiatan serta manfaat sumber daya air oleh manusia yang berada di perairan tersebut. Pasal 1 ayat 11 PP. No 82 Tahun 2001 mendefinisikan Pencemaran air adalah masuknya atau dimasukkannya makhluk hidup, zat, energi dan atau komponen lain ke dalam air oleh kegiatan manusia, sehingga kualitas air turun sampai ke tingkat tertentu yang menyebabkan air tidak dapat berfungsi sesuai dengan peruntukannya. Definisi pencemaran air tersebut dapat diuraikan sesuai makna pokoknya menjadi tiga (3) aspek penyebab atau pelaku dan aspek akibat (Setiawan, 2001 dalam Warlina, 2004). Pendugaan pencemaran sungai dapat dilakukan dengan melihat pengaruh polutan terhadap kehidupan organisme perairan dan lingkungan. Unit penduga adanya pencemaran tersebut diklasifikasikan dalam parameter fisika, kimia dan biologi. Tujuan penelitian ini adalah untuk menganalis parameter fisika-kimia yang meliputi suhu, oksigen terlarut (DO), kekeruhan dan BOD (biology oxygen demand), perairan Sungai Tondano di kelurahan Ternate Baru untuk mendeteksi pencemaran sungai mengacu pada Baku Mutu Kelas II PP. No.82 Tahun 2001 Tentang Pengelolaan Kualitas Air dan Pengendalian Pencemaran Air.

\section{BAHAN DAN METODE}

\section{Tempat dan Waktu Penelitian}

Penelitian ini dilakukan di perairan sungai Tondano di wilayah Kelurahan Ternate Baru Kota Manado. Penelitian dilakukan pada bulan januari sampai maret 2012. Lokasi penelitian dapat dilihat pada gambar 1 .

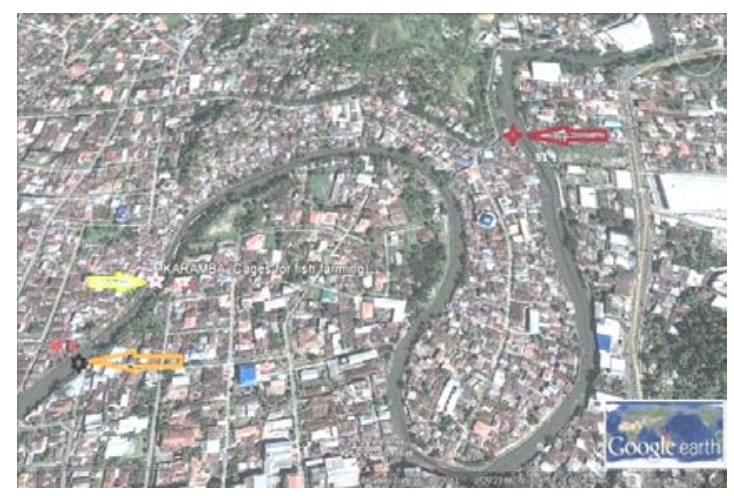

Gambar 1. Lokasi Penelitian

\section{Teknik Pengambilan Sampel}

Lokasi pengambilan sampel ditentukan dengan cara purposive sampling, dimana terdapat tiga(3) stasiun pengambilan sampel, masing-masing stasiun 2 titik pengambilan. Waktu pengambilan sampel dilakukan pada pagi (08.00), siang (11.00) dan sore (15.00). Jarak antara stasiun 1 ke stasiun 2 berdasarkan ploting lokasi peta aplikasi Google Earth di peroleh 1,8 km mengikuti arah arus ke laut, sedangkan jarak antara stasiun 2 ke 3 berkisar 50 meter ke arah laut (Gambar 1). Dari pengamatan lokasi yang dilakukan, stasiun 1 adalah wilayah perairan sungai yang dimanfaatkan sebagai sarana transportasi penyeberangan sungai, stasiun 2 adalah pusat budidaya karamba ikan dan stasiun 3 adalah lokasi akhir peletakan karamba ikan. Alat yang dipergunakan dalam penelitian ini adalah ; Thermometer air raksa, $\mathrm{pH}$ digital-bante, Turbidity meter TU 2016bante, spektrofotometer, botol sampel, alat dokumentasi dan tulis menulis. Bahan yang digunakan adalah; sampel air sungai, aquades, cairan kalibrasi 0 NTU dan 100 NTU. Tabel di bawah ini adalah peralatan dan metode uji yang digunakan. 
Tabel 1. Peralatan dan Metode Uji yang digunakan

\begin{tabular}{|l|l|l|l|l|}
\hline No & Alat & Parameter & Satuan & Metode \\
\hline & \multicolumn{4}{|c|}{ Fisika } \\
\hline & Termometer & Suhu & ${ }^{0} \mathrm{C}$ & In situ \\
\hline & TU-2016 & Kekeruhan & NTU & In situ \\
\hline & \multicolumn{5}{|c|}{ Kimia } \\
\hline & - & DO & $\mathrm{Mg} / \mathrm{L}$ & $\begin{array}{l}\text { SNI.06-6989.14- } \\
2004\end{array}$ \\
\hline & - & BOD & $\mathrm{Mg} / \mathrm{L}$ & $\begin{array}{c}\text { SNI.06-6989.72- } \\
2009\end{array}$ \\
\hline
\end{tabular}

Pengambilan sampel dilakukan dengan cara memasukkan botol sampel yang telah dimodifikasi dengan pemberat. Botol sampel tersebut dimasukan sampai pada kedalaman yang diinginkan $(0.5 \mathrm{~m}$ dari permukaan perairan dan $0.5 \mathrm{~m}$ dari dasar perairan) lalu ditarik penutup botolnya. Setelah botol sampel penuh terisi air yang ditandai dengan keluarnya gelembung udara, maka botol sampel langsung ditarik ke permukaan untuk mengisi botol sampel lain yang telah diberi label.

\section{Pengumpulan dan Analisis Data}

Pengukuran parameter kualitas air dilakukan dengan dua cara yaitu in situ untuk suhu dengan thermometer, Kekeruhan dengan menggunakan Turbidity Meter (TU2016 bante). Untuk oksigen terlarut (DO) dan BOD, sampel diambil pada tiap titik stasiun pengambilan sampel dengan menggunakan botol sampel standar 2 liter. Untuk menjaga jangan sampai terjadi kontaminasi, botol berisi sampel segera diberi label dan dimasukkan dalam coll box berisi es batu. Kemudian sampel dibawa ke laboratorium Balai Teknik Kesehatan Lingkungan dan Pemberantasan Penyakit Menular Kelas 1 Manado (BTKL) untuk dianalisis indikatornya.

\section{HASIL DAN PEMBAHASAN}

Hasil pengukuran dan analisis parameter fisika kimia air dapat dilihat pada tabel 2.

Tabel 2. Kualitas air Sungai Tondano di wilayah Kelurahan Ternate Baru Kota Manado.

\begin{tabular}{|c|c|c|c|c|c|c|c|c|c|c|}
\hline \multirow{2}{*}{$\begin{array}{c}\text { Waktu } \\
\text { Pengukuran }\end{array}$} & \multirow{2}{*}{ Parameter } & \multicolumn{3}{|c|}{ Stasiun I } & \multicolumn{3}{|c|}{ Stasiun II } & \multicolumn{3}{|c|}{ Stasiun III } \\
\hline & & 08.00 & 11.00 & 17.00 & 08.00 & 11.00 & 17.00 & 08.00 & 11.00 & 17.00 \\
\hline \multirow{4}{*}{ Sampling I } & Suhu & 26 & 27,5 & 27 & 26,3 & 27,5 & 27 & 26,4 & 27,6 & 26,7 \\
\hline & Kekeruhan & 80 & 150 & 37,9 & 110 & 68 & 77 & 115 & 143 & 90 \\
\hline & DO & 7,5 & 7,5 & 7,4 & 7,5 & 6,3 & 7,2 & 7,2 & 7,5 & 7,2 \\
\hline & BOD & 41,5 & 44 & 23,6 & 15,5 & 38,8 & 30,5 & 35 & 25,4 & 31,5 \\
\hline \multirow{4}{*}{ Sampling II } & Suhu & 27 & 27,8 & 27 & 26,9 & 27,9 & 26,6 & 26,4 & 26,7 & 26,7 \\
\hline & Kekeruhan & 56 & 43 & 38 & 55 & 53 & 45 & 43 & 59 & 37,9 \\
\hline & DO & 6,8 & 7 & 7,4 & 7,5 & 6,3 & 7,4 & 6,3 & 7 & 7,2 \\
\hline & BOD & 28 & 28,5 & 27,8 & 37 & 39 & 38,2 & 43 & 41,5 & 45 \\
\hline
\end{tabular}


Hasil pengukuran suhu yang dilakukan pada tiap stasiun di dapatkan kisaran nilai $26^{\circ} \mathrm{C}$ 27,8.

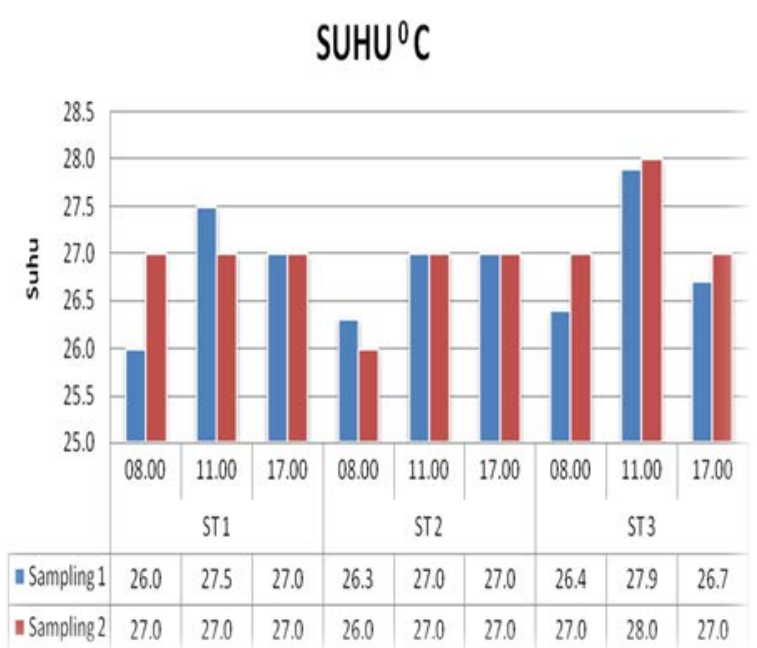

Gambar 2. Suhu air sungai di Kelurahan Ternate Baru

Hutapea (1990) dalam Yazwar (2008) menyatakan bahwa perbedaan suhu pada suatu perairan dipengaruhi oleh 4 faktor, yakni: (1) variasi jumlah panas yang diserap, (2) Pengaruh konduksi panas (3) pertukaran tempat massa air secara lateral oleh arus dan (4) pertukaran air secara vertikal. Kenaikan suhu air di badan air penerima, saluran air, sungai, danau dan lain sebagainya akan menimbulkan akibat sebagai berikut: 1) Jumlah oksigen terlarut di dalam air menurun; 2) Kecepatan reaksi kimia meningkat; 3) Kehidupan ikan dan hewan air lainnya terganggu. Jika batas suhu yang mematikan terlampaui, maka akan menyebabkan ikan dan hewan air lainnya mati. Ikan dan organisme air budidaya lainnya tidak memiliki alat untuk mengontrol suhu tubuh yang berubah akibat lingkungan (Beveridge, 2004). Kisaran nilai pengukuran suhu di tiap stasiun menunjukkan kondisi yang masih memungkinkan dukungan metabolisme organisme akuatik untuk hidup.
Hasil pengukuran DO dapat dilihat pada gambar 3.

\section{$\mathrm{DO}(\mathrm{mg} / \mathrm{L})$}

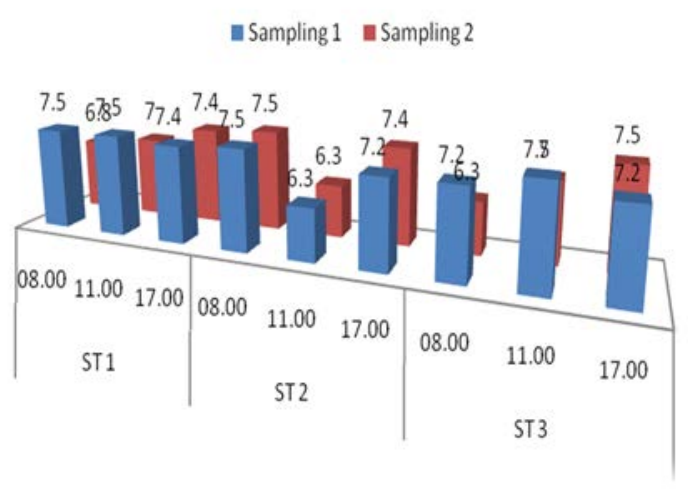

Gambar 3. Oksigen Terlarut (DO) air sungai di Kelurahan Ternate Baru

Grafik di atas menunjukkan oksigen terlarut berkisar 6,3-7,5 (mg/L). Mengacu pada Peraturan Pemerintah No.82 Tahun 2001, Baku Mutu Air Kelas II, maka hasil pengukuran yang diperoleh masih dalam kondisi yang baik dimana nilai baku mutu untuk DO adalah 7,2. Oksigen diperlukan oleh ikan-ikan untuk menghasilkan energi yang sangat penting bagi pencernaan, asimilasi makanan dan pemeliharaan keseimbangan osmotik. Jika persediaan oksigen di perairan sedikit maka perairan tersebut tidak baik bagi ikan dan organisme akuatik lainnya, (Wardana, 1995 dalam Siagian, 2009). Menurut Effendy, 2003 menyatakan, kadar oksigen berfluktuasi secara harian (diurnal) dan musiman, tergantung pada percampuran (mixing) dan pergerakan (turbulance) massa air, aktivitas fotosintesis, respirasi, dan limbah (effluent) yang masuk ke badan air. Dekomposisi bahan organik dan oksidasi bahan anorganik dapat mengurangi kadar oksigen terlarut hingga mencapai nol (anaerob). Dalam usaha kegiatan karamba ikan, kondisi ini dapat mempengaruhi pertumbuhan bahkan kematian ikan. 
Hasil pengukuran kekeruhan dapat dilihat pada Gambar 4 di bawah ini.

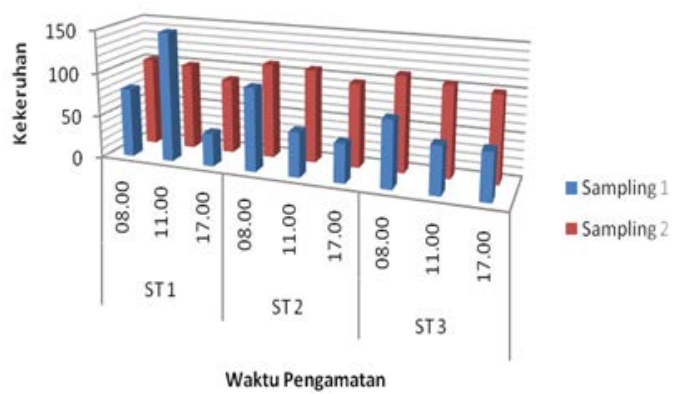

Gambar 4. Kekeruhan air sungai di Kelurahan Ternate Baru

Grafik di atas menunjukkan kisaran nilai 37,9 - 150 NTU dimana nilai tersebut sudah melebihi Baku Mutu Air Kelas II, PP. No. 82. Tahun 2001. Tingginya nilai pengukuran kekeruhan dapat diakibatkan oleh erosi yang menyebabkan terjadinya penggerusan tanah di sepanjang lintasan air, juga akibat kegiatan penambangan galian c dari arah hulu. Dengan mengetahui kekeruhan suatu perairan dapat diketahui sampai dimana masih ada kemungkinan terjadinya proses asimilasi dalam air (Asmawi,1986). Pengaruh tingginya nilai kekeruhan pada suatu perairan dapat menyebabkan 1) Abrasi langsung terhadap insang binatang air atau jaringan tipis dari tumbuhan air; 2) Penyumbatan insang ikan at au selaput pernapasan lainnya; 3) Menghamb at tumbuhnya/smothering telur atau kurangnya asupan oksigen karena terlapisi oleh padatan; 4) Gangguan terhadap proses makan, termasuk proses mencari mangsa dan menyeleksi makanan ( terutama bagi predation dan filter feeding; 5) Gangguan terhadap proses fotosintesis oleh ganggang atau rumput air karena padatan menghalangi sinar yang masuk; 6) Perubahan integritas habitat akibat perubahan ukuran partikel.
Hasil pengukuran BOD dapat dilihat pada gambar 5 di bawah ini.

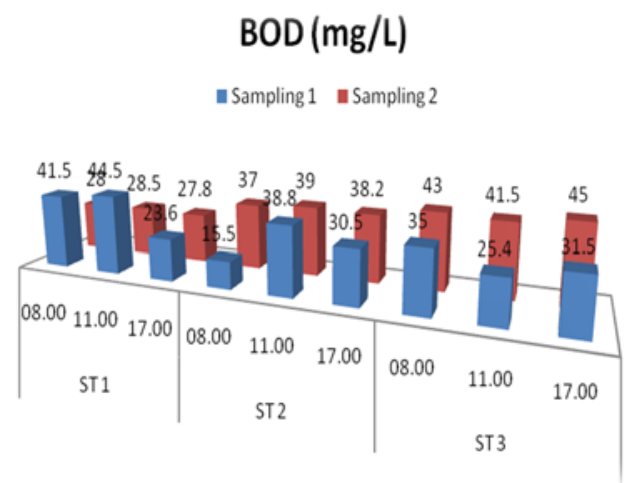

Gambar 5. Nilai BOD air sungai di Kelurahan Ternate Baru

Kisaran nilai yang didapat untuk parameter ini adalah 15,5-44 mg/L. Nilai ini menunjukkan kondisi status cemar berat ditinjau dari baku mutu Kelas II PP No. 82 Tahun 2001 yang ditentukan yaitu $3 \mathrm{mg} / \mathrm{L}$. Parameter BOD secara umum banyak dipakai untuk menentukan tingkat pencemaran air buangan. Penentuan BOD sangat penting untuk menelusuri aliran pencemaran dari tingkat hulu ke muara (Salmin, 2005). Aktivitas masyarakat dalam bentuk buangan limbah domestik, pakan ikan dan industri di lokasi penelitian dan sekitarnya mempengaruhi BOD perairan.

\section{KESIMPULAN}

1. BOD dan kekeruhan air sungai Tondano di kelurahan Ternate Kota Manado telah melewati Baku Mutu Air Kelas II PP No. 82 Tahun 2001 dan dikategorikan tercemar.

2. Penyebab utama pencemaran air di area ini adalah limbah domestik, pakan ikan dan limbah industri. 


\section{DAFTAR PUSTAKA}

Asmawi, Suhaili, 1986. Pemeliharaan Ikan dalam Karamba. PT. Gramedia Jakarta.

Azwir, 2006. Analisa Pencemaran Air Sungai Tapung Kiri Oleh Limbah Industry Kelapa Sawit PT. Peputra Masterindo di Kabupaten Kampar. Tesis.

Beveridge, Malcolm C. M. 2004. Cage aquaculture/Malcolm C. M. Beveridge. - 3rd ed. Blackwell Publishing Ltd.

Effendi, H. 2003. Telaah Kualitas Air: Bagi Pengelolaan Sumber Daya dan Lingkungan Perairan. Kanisius: Yogyakarta.

Hunta. 2011 . Daya Tampung Beban Pencemaran Bahan Organic Dan Alternatif Pengendaliannya Pada Sungai Tondano. Makalah BTKL Manado.

Peraturan Pemerintah No. 82.Tahun 2001. Tentang Pengelolaan Kualitas Air dan Pengendalian Pencemaran.

Peraturan Pemerintah Nomor 38 Thn 2011 Te ntang Sungai.

http://www.presidenri.go.id/Dokumen UU.php/631.pdf

diunduh 26-Mei-2013; 22:35
Salmin. 2005. Oksigen Terlarut (DO) Dan Kebutuhan Oksigen Biologi (BOD) Sebagai Salah Satu Indikator Untuk Menentukan Kualitas Perairan. Oseana, Volume XXX, Nomor 3, 2005:21-26.

Siagian, C. 2009. Keanekaragaman Dan Kelimpahan Ikan Serta Keterkaitannya Dengan Kualitas Perairan Di Danau Toba Balige Sumatra Utara. Tesis UNSU.

Wijaya, H.K. 2009. Komunitas Perifiton Dan Fitoplankton Serta Parameter FisikaKimia Perairan Sebagai Penentu Kualitas Air Di Bagian Hulu Sungai Cisadane, Jawa Barat. Skripsi IPB.

Warlina. 2004. Pencemaran Air: Sumber, Da mpak dan Penanggulangannya. Makal ah Pengantar ke falsafah Sains. Bogor: IPB.

Yazwar, 2008. Keanekaragaman Plankton dan Keterkaitannya dengan Kualitas Air di Parapat Danau Toba. Tesis PascaSarjana UNSU. 